\title{
AUTONÓMIA: ELMÉLET ÉS GYAKORLAT
}

\author{
(Autonomy: Theory and Practice)
}

MIKLÓSNÉ ZAKAR ANDREA

\begin{abstract}
Kulcsszavak:
önrendelkezés autonómia személyi autonómia területi autonómia

Jelen tanulmány, jelentös magyar és föleg angol nyelvü szakirodalom feldolgozása révén, az autonómia kérdéskörének elméleti aspektusait járja körbe, és igyekszik azt egybevetni a gyakorlati alkalmazással. A szerzö tanulmányában egyrészt összegezni kívánja az autonómia fogalmának különbözö definícióit, másrészt feltérképezi azokat a nemzetközi jogi dokumentumokat, amelyek utalnak az autonómiához való jogra, illetve bemutatja az autonómia különbözö típusait.
\end{abstract}

Az autonómia kérdése napjaink egyik meghatározó problematikájává vált KeletKözép-Európában is. Fogalma és típusai gyakran kerülnek górcső alá, miközben a nyugat-európai modellek felé is egyre nagyobb érdeklődéssel fordulunk. Ha az autonómia fogalmát igyekszünk meghatározni, rájövünk, hogy a gyakorlatba ültetés sokfélesége és bonyolultsága okán predesztinált arra, hogy tudományos definiálása nehézkes legyen, jogi aspektusból pedig szinte meghatározhatatlanná váljék. Viszont éppen a sokrétüsége és rugalmas eszköztára teszi alkalmassá az oly különböző államok számára az alkalmazását. Széles értelemben az autonómia arra ad jogot, hogy az egyén vagy az egyének egy csoportja maga döntsön bizonyos meghatározott kérdésekben. A történelem során ez a jog több kontextusban is megjelent, például a települések autonómiájában.

\section{Az autonómia fogalma}

Etimológiai szempontból az autonómia terminus két görög szóból származik: az auto (jelentése 'ön') és a nomos (jelentése 'törvény, szabály') szavakból. Így az autonómia szó eredeti jelentése arra a jogra vonatkozott, amely által valaki megalkothatja saját törvényeit. Napjainkban a fogalom három különböző tudományterület keretein belül használatos: a filozófiában, a természettudományokban és a jog, politikatudomány, illetve nemzetközi kapcsolatok terén.

A filozófiában először Machiavellinél találkozunk az autonómiával, öt követi később Kant, Mill és Hume is. A természettudományok számára az autonómia a szervezet függetlenségét jelenti, valamint azt az állapotot, amelyben egy jelenség csak saját törvényeihez alkalmazkodik és nem alanya magasabb törvényeknek (Lindley 1986).

Az autonómia fogalmának legsokoldalúbb használata azonban a jogban és politikatudományban érhető tetten. E tekintetben viszont a leírások zavartkeltően sokfélék, 
amely okán néhány szakember (, Lindley 1986; Lapidoth 1997) felhívja a figyelmet arra, hogy válasszuk külön a fogalmat (concept) és a hozzá kapcsolódó nézeteket, elméleteket (conceptions). Mert miközben az autonómia fogalmáról van valamiféle általános megegyezés (az érték voltában és a hozzá kapcsolódó fogalmakban), addig az értelmező elméletek és felfogások igen sokfélék és különbözőek (Lapidoth 1997, 29). A következőkben összefoglaljuk azon kutatóknak a fogalommal kapcsolatos definícióját, leírását, amelyeket a feldogozott szakirodalom felölel, azzal a megjegyzéssel, hogy nem minden szakíró próbálkozott egyéni meghatározásokat adni.

Rudolf Bernhardt kétféle definíciót ad: egy tágabb és egy szükebb meghatározást. A szélesebb lehatárolás szerint az autonómia nem más, mint egy egyén vagy egy entitás autonóm önmeghatározása, illetve a képessége, hogy saját ügyeit külső behatás nélkül kezelje. Utal ezzel az egyházi, a városi vagy az egyetemi autonómiára. A szükebb definícióval Bernhardt a kisebbségvédelemre és a kisebbség önrendelkezésére utal, ilyen értelemben pedig szorosan köthető az emberi jogok kérdésköréhez is (Bernhardt 1981).

Luis B. Sohn a fogalmat élesen elkülöníti a függetlenségtöl és teljes önrendelkezéstől, és az autonómiát magát inkább önkormányzásnak (self-rule, selfgovernment) tekinti, amely lehetővé teszi egy régióban bizonyos speciális kérdéskörök esetében közvetlen kontroll gyakorlását, miközben egy nagyobb politikai entitás visszatartja a hatalom egy részét a közös érdekek szolgálatában (Sohn 1981).

Yoram Dinstein szerint az autonómia nem egyéb, mint önkormányzási lehetőség, a problémája pedig mindig az, hogy vonakodva adják, és hálátlanul fogadják (Dinstein 1981).

Hurst Hannum széles körủ definíciójában kitér a személyi és politikai autonómiára egyaránt, mondván, hogy mindkettő azt a jogot jelenti, hogy 'más' és 'magára maradt' lehessen az alany, illetve feladata, hogy megőrizze, megóvja és támogassa azon értékeket, amelyek törvényesen hozzáférhetetlenek a társadalom többi része számára (Hannum 1992).

Yash Ghai szerint az autonómia egy olyan egység, amely megengedi egy elkülönülő identitással rendelkezö etnikumnak vagy más csoportnak, hogy a számukra speciális jelentőségü kérdésekben közvetlen kontrollt gyakorolhassanak, miközben egy nagyobb entitásnál marad az a hatalom, amely a közös ügyekért felelös (Ghai 2000).

Hans-Joachim Heintze (1998) igen realista módon úgy véli, hogy az autonómia egy általános jogi terminus, amelynek tartalmat kell adni, és úgy véli, hogy az autonómia-megoldások egyetlen korlátja a szuverenitás (Heintze 1998).

Ruth Lapidoth maga is összesíti az autonómia-definíciókat a 20. század elejétöl kezdve, és kitér olyan kutatókra, mint George Jelli, aki számára az autonómia a szuverenitás szinonimája, vagy Henry Berthélémy, akinél a decentralizációval egyenértékü. Paul Laband számára törvényhozó hatalmat jelent, de különbözik a szuverenitástól, lévén, hogy a szuverén által meghatározott keretek között működhet. Heinrich Dörge olyan térségekre vonatkoztatja, mint pl. az Áland-szigetek, de nem ismeri el a szovjet ,autonóm” területek, köztársaságok, régiók valódi autonómiáját. James Crawford szerint autonóm térség egy régió az államon belül, mely 
általában etnikai vagy kulturális megkülönböztető jegyeket hordoz, és amely régió külön hatalmat kap a belső önigazgatásra, bármilyen fokú legyen is az anélkül, hogy az államtól, amelyhez tartoznak, elszakadnának. Végül Lapidoth Heinrich Oberreuter definícióját tekinti az általa ismert legrövidebbnek, mely szerint az autonómia a szabad önrendelkezés lehetősége egy jogilag már létező rend keretein belül (Lapidoth 1997).

Mindezen sokrétüség, az elméleteknek ezen sokfélesége és a gyakorlatban tapasztalt különbségek és variánsok okán Lapidoth az autonómia „eklektikus”, különböző elemekből összeállított leírását javasolja, mely definíció - saját bevallása szerint - nem fog ráilleni minden gyakorlatban megvalósult autonómiára. Ilyen formában az általa javasolt meghatározás, amelyben kifejezetten a területiséget emeli ki: „A területi politikai autonómia egy berendezkedés, amelyet olyan csoportnak nyújtanak, amely az állam népességének többségétől eltérő, de amely az adott régióban többséget alkot, egy eszköz, amely által a csoport ki tudja fejezni elkülönülő identitását." (Lapidoth 1997, 33)

Összesítve az elképzeléseket és a gyakorlatba ültetett autonómiák müködését, a legáltalánosabb megfogalmazásban talán a következőképpen definiálható: autonómiának tekinthetö egy adott közösségnek valamilyen érdekképviseleti vagy akár bizonyos igazgatási jogosítványokkal bíró intézményrendszerrel való felruházása, mely jogosítványok kötődhetnek a közösség által lakott terület egészéhez, esetleg egy részéhez, de átfogja a közösséghez tartozó vagy oda tartozni akaró (identitást felvállaló) összes individuumot.

\section{Autonómia a nemzetközi jogban}

Az autonómiát néha, mint a nemzetközi jog elvét emlegetik, ennek ellenére egyelöre az autonómiához való jogot semmilyen nemzetközi jogi aktus nem konkretizálja. Inkább a szokásjog körébe tartozik, amely az egyre szaporodó gyakorlati példákból adódik (Heintze 1998). Mivel a definiálás nehézkes, a nemzetközi jog nem szabályozza, így az autonómia gyakorlata - mint arra már utaltunk - igen változatos és sajnos esetleges.

Amennyiben a területi autonómiát részleges önrendelkezési jognak tekintjük (Hannikainen 1998), (a kulturális/személyi autonómia sokkal szerényebb forma és kevésbé köthető a nemzetközi jog önrendelkezési jogához), úgy nemzetközi jogi kialakulását az önrendelkezési jog kialakulása mentén értelmezhetjük. Ehhez kapcsolódóan a szakirodalom a kisebbségi és a kollektív jogok mentén igyekszik értelmezni, azokból származtatná. Felvetődik azonban a kérdés, hogy ezeknek elismerése a nemzetközi emberi jog által szolgáltat-e normatív alapelveket egy speciális autonómia-formához (Thornberry 1998).

Habár a nemzetközi dokumentumok, a nemzetközi jog és a közösségi jog sem rendelkezik az autonómiáról, sőt azt mondhatjuk, hogy a nemzetközi jogi elfogadtatása nehézkes és sok akadályba ütközik, ennek ellenére születtek már ez irányú, 
jogilag nem kötelező erejű megállapodások, nyilatkozatok. Ezek legfőképpen a kilencvenes évektől kezdődően szaporodnak, mivel ez az a korszakhatár, ami után az autonómiát nem veszélyes, szecessziót megelöző lépésként értelmezik az államok, hanem kikristályosodik a vélemény, miszerint az autonómia létrehozása egy hatékony garancia arra, hogy a területi egység megörizhető legyen egy etnikai konfliktusokkal terhes államban. Nyugat-Európában is ekkor kap valódi autonómiát Dél-Tirol, Katalónia és Skócia is.

Az Európai Biztonsági és Együttmüködési Értekezlet (EBEÉ) Koppenhágában lefektetett dokumentuma ${ }^{l}$ 1990-ben először említi meg az autonómiát, de csak mint egy „lehetséges eszközt” a kisebbségek identitásának védelmében, viszont nem rögzíti jogként, és nem állít fel semmilyen autonómia-normát. Mindazonáltal az első dokumentum, mely szabályozni igyekszik a kisebbségi kérdéskört, normákat állítva az államok elé. A 35. paragrafus említi és a kisebbségek számára ajánlja a helyi és autonóm igazgatás lehetőségét mint alternatívát a specifikus történelmi és területi körülményeknek megfelelően. Mint ilyen, ez a dokumentum korszakváltó. Az EBEÉ nemzeti kisebbségi szakértőinek genfi tanácskozása egy évvel később egy jelentést készített, amely már akkor leszögezte, hogy a Koppenhágában elöirányzott helyi és regionális autonóm igazgatás kérdése a gyakorlatban pozitív eredményeket hozott.

Erre alapoz az Európai Biztonsági és Együttmüködési Szervezet (EBESZ, az EBEÉ utódja) által kibocsátott Lundi Ajánlások a nemzeti kisebbségek hatékony részvételéröl a közéletben címü 1999-es dokumentum is, amely valószínüleg a legátfogóbb módon utal az autonómia kérdéskörére a nemzetközi dokumentumok közül (Wolff-Weller 2005). Kifejti az autonómia területi vonzatának problematikáját, ezzel körvonalazva az EBESZ területi autonómiára vonatkozó álláspontját, és ajánlást fogalmaz meg a kulturális vagy személyi autonómiával kapcsolatban is.

Az ENSZ Kisebbségi Nyilatkozata (az 1992. december 18-án kelt 47/135. számú nyilatkozat) ${ }^{2}$ nem szól az autonómiáról, habár a cél az lett volna, de inkább csak alternatív terminológiát használva tárgyaltak, utalva az „önmenedzselésre” (selfmanagement) vagy az „önigazgatásra” (self-administration), habár később ezeket el is vetették. Mindenesetre ez a nyilatkozat a kollektív jogok elismerésében egy köztes állomásnak tekinthető (Thornberry 1998).

Az Európa Tanács munkássága is figyelemre méltó e tekintetben, hiszen az égisze alatt készült 1985-ban a Helyi Önkormányzatok Európai Chartája, amely a szubszidiaritás elve mentén fogalmaz meg jelentős megállapításokat, amelyek fontosak lehetnek a területi autonómia támogatói számára. „A közfeladatokat általában elsősorban az állampolgárokhoz legközelebb álló közigazgatási szervnek kell megvalósítania. A feladatoknak más közigazgatási szervre történő átruházása a feladat természetétől és nagyságától, valamint hatékonysági és gazdaságossági követelményektől függ." (4. cikk, 3. bekezdés) ${ }^{3}$ Később az Európai Uniót létrehozó Maastrichti Szerződés beemeli az Unió elsődleges joganyagába a szubszidiaritás elvét, megadva számára a méltó helyet a közösségi joganyagban. 
A szubszidiaritás elvének terjedését mutatja a Helyi és Regionális Önkormányzatok Állandó Értekezletének (az előbb említett Kongresszus elődje) 1992 márciusában elfogadott dokumentuma ${ }^{4}$ is, amely hangot adott a nemzeti, etnikai és nyelvi kisebbségek melletti elkötelezettségének, és elítélte a Közép- és Kelet-Európa friss demokráciáiban újraéledő nacionalizmust. A dokumentum kimondja, hogy fontosnak tartják a „széleskörü hatalommegosztást a központi kormányzat, a regionális és a helyi autoritások között”, valamint megnevezik a kisebbségek jogát arra, hogy „,a szubszidiaritás elve mentén, minden állam igazgatási szerkezetét tiszteletben tartva szerepet játszanak a közigazgatásban.” (15. paragrafus, II. 4, idézi Lewis-Anthony 1998, 320). Ilyen formán a dokumentum közvetlen kapcsolatot teremt az autonómia elve és a kisebbségi jogok között (Lewis-Anthony 1998).

Jelentős dokumentum, habár kifejezetten autonómiáról ez sem rendelkezik, a Regionális vagy Kisebbségi Nyelvek Európai Chartája (1992), amely azon túl, hogy felhívja a figyelmet a nyelvi és kulturális sokszínüség jelentőségére és megőrzésének fontosságára, néhány olyan megállapítást tesz, amely vagy a területi, vagy a személyi autonómia alapjaiként, egyik érveként is használható:

„,...'regionális vagy kisebbségi nyelv használatának területén' az a földrajzi terület értendő, ahol ez a nyelv olyan számú személy kifejezési eszköze, amely indokolja a jelen Charta által elöírt különbözö védelmi és ösztönző intézkedések meghozatalát" (1. cikk, b. pont: Majtényi-Vizi 2003, 137), és fontos „minden egyes regionális vagy kisebbségi nyelv földrajzi körzetének tiszteletben tartása annak érdekében, hogy a fennálló vagy később létesítendő közigazgatási felosztás ne képezze e regionális vagy kisebbségi nyelv támogatásának akadályát" (7. cikk, 1/b. pont: MajtényiVizi 2003, 138). Látható, hogy ezeknek a jogoknak az elismerése egy lépéssel közelebb hozza az autonómia kérdését is.

Az Európa Tanács Parlamenti Közgyülésének 1201-es ajánlása ${ }^{6}$ 1993-ban az addigi legexplicitebb autonómia fogalom-használatot tartalmazza az Emberi Jogok Európai Egyezményére vonatkozó javaslatokkal egyetemben. A „különleges státusz" fogalmának bevezetése, mint azt az alábbi passzusban is látható, értelmezhető akár területi autonómiaként is, de az autonóm közigazgatási szervekre való utalás is nagy elörelépés az előző dokumentumokhoz viszonyítva.

„Azokban a régiókban, ahol egy nemzeti kisebbséghez tartozó személyek többséget alkotnak, ezen személyeknek jogukban áll, hogy sajátos történelmi és területi helyzetüknek megfelelő és az állam jogrendszerével összhangban álló helyi vagy autonóm közigazgatási szervekkel, vagy különleges státusszal rendelkezzenek." (3. fejezet, 11. cikkely: Majtényi-Vizi 2003, 155).

Az 1997-es év áttörést hozott az Európa Tanács munkájában a vizsgált kérdéskörünket illetően. Az Európa Helyi és Regionális Hatóságainak Kongresszusa munkálatainak és egy Olaszországban tartott konferenciának eredményeképpen született meg a Föderalizmus, regionalizmus, helyi autonómia és kisebbségek címü határo$\mathrm{zat}^{7}$, amely komoly elörelépést jelent. A határozat 6 . pontja kimondja, hogy a föderalizmus, regionalizmus és a helyi autonómia nem más, mint a szubszidiaritás elvé- 
nek különböző alkalmazásai. A 10. pont konkretizálja a területi autonómia kérdését, vallva, hogy bizonyos körülmények között ott, ahol egy kulturális vagy nyelvi kisebbséghez tartozó személyek koncentrációja nagy (egy nagyvárosban, provinciában vagy régióban), a területi autonómia egy nagyon hatékony eszköz a kisebbségek problémáinak a megoldására, elkerülve a szeparatista tendenciákat. A kulturális autonómia tekintetében a 11. pont kimondja, hogy bizonyos körülmények között kiegészítheti az önkormányzást, miközben alapvető része a területi autonómiának. Ilyen formában a két autonómia-formát a dokumentum összekapcsolja. Érdekes annak a kérdésnek a hangsúlyozása, amelyet a 13. pont tartalmaz, miszerint az aláírók meggyőződése, hogy a kisebbségeknek nyújtott autonómia nem csupán a föderális vagy regionalizált struktúrával rendelkező országok körére korlátozódik, hanem lehetséges és ajánlott az unitárius államok számára is.

Ugyanezzel a felhanggal rendelkezik a Regionális Autonómia Európai Chartája, amelyet az Európa Tanács Közgyülése (hosszadalmas elömunkálatot követően) végleges formában szintén 1997-ben fogadott el. Kimondja, hogy az autonóm régióknak egy állam struktúráján belül olyan helyi tradíciókkal kell rendelkezniük, amelyek különböznek a nemzeti hagyományoktól. Az autonóm régiók tiszteletben tartják az állam területi integritását, és a döntéshozó hatalommal való felruházásuk az Európa Tanács tagállamai közti egységet is szolgálja. Ezek a megállapítások egyértelmüen pozitívan járulnak hozzá a területi autonómiák ügyéhez (Lewis-Anthony 1998).

Az autonómia kérdésének elfogadtatása felé tett hatalmas lépésként értelmezhető az Európa Tanács 2003-ban elfogadott 1334-es számú határozata, amely Az autonóm régiók pozitív tapasztalatai, mint a konfliktusok megoldásának lehetséges eszközei Európában (Gross jelentés) címet viseli ${ }^{8}$. Példaként állítja a már müködő európai autonómiákat azon országok elé, amelyek a kilencvenes évektől kezdve új demokráciaként meg-megújuló konfliktusokat, így etnikai problémákat is hordoznak. A dokumentumban az Európa Tanács definiálja a saját területi és a kulturális autonómia elképzelését:

„A 'területi autonómia' kifejezés olyan, általában szuverén állam által elfogadott rendelkezésre utal, melynek során egy bizonyos terület lakosságát szélesebb jogkörrel ruházzák fel, mely tükrözi speciális földrajzi helyzetüket, valamint védi és elösegíti kulturális és vallási hagyományaikat. A 'kulturális autonómia' kifejezés a nyelvi és kulturális jogok gyakorlásának lehetővé tételét jelenti. Az esetek többségében ennek együtt kell járnia a decentralizáció elvének alkalmazásával." (11. pont: Majtényi-Vizi 2003, 185) Mindezek mellett egy olyan minimum kritériumrendszert is felvázol (22. pont), melynek betartását ajánlja azon országok számára, amelyek autonómiát vezetnek be a saját területükön.

Az Európai Unió autonómiához való viszonya kétoldalú. Egyrészt magát az integrációt is felfoghatjuk úgy, mint a tagállamok által alkotott autonóm szervezetet. Másrészt a politikai autonómia szupra- és szubnacionális szintekre való kiterjesztése egy olyan jelenség, amely az állam politikai hatalmának európaizálódásához kötődik (Bullain 1998, 343). De vajon egy szupranacionális építményben, mint amilyen 
az Európai Unió, milyen módon alkalmazható az autonómia nemzetalatti, regionális szinten? Bullain kifejti, hogy az európai politikai színtér felépítése hatalmas problémákat vet föl az autonómiák önkormányzatai számára. Mivel a tagállamok már eleve veszítettek hatalmukból az integrációba való belépéskor, ezért kiegyensúlyozva ezt a deficitet, monopolizálják a közös munkafolyamatban való képviseletet. Így a régiók nem képviseltethetik magukat a közösségi döntéshozatali mechanizmusban, kivéve a német és az osztrák Landokat, amelyeknek részvételét az Európai Unió Tanácsában és különböző bizottságokban a vonatkozó államok alkotmányosan rögzítették. A régiók politikai autonómiáját ilyen formában, specifikusan a közösség nem ismeri el. Nem tesz különbséget föderális és unitárius állam között. Erre az anomáliára esetlegesen megoldás lehet a „Régiók Európája” jövőkép.

A Maastrichti Szerződés létrehozta a Régiók Bizottságát, mint egy új intézményt, de sem összetételében, sem jogosítványaiban nem különíti el az autonóm régiókat. Ez az intézmény pusztán képviseli a régiókat és a helyi testületeket, és csak tanácskozási joggal bír bizonyos kérdésekben. Ezen bizottság felállításának célja tehát nem az volt, hogy intézményesítse a regionális politikai hatalom képviseletét (Bullain 1998).

Elmondható tehát, hogy az autonómiához való jog kérdésköre napjaink egyik nagy nemzetközi jogi kihívása. Hiszen láthattuk, hogy alapvetően a soft law területét érintik egyelöre, vagyis a nem szerződési természetủ ajánlások és határozatok szintjén jelennek meg rá utaló leírások, körülírások. Az is egyértelmü, hogy alapvetően a kisebbségekkel, illetve a kisebbségi jogokkal kapcsolatosan merül fel az autonómia problematikája, de ezekben a nemzetközi dokumentumokban közös, hogy „külön cikkben erösítik meg az államok szuverenitásának elvét és területi integritásának védelmét, hangsúlyozva, hogy egyetlen kisebbségi jog sem gyakorolható ezen elvekkel ellentétesen" (Vizi 2004, 22). A kisebbségi jogok rendszerét nem hiába hívja a szakirodalom „szégyenlős kisebbségvédelemnek” (Kovács Péter szavait idézi GerencsérJuhász 2001, 21, 31; ill. lásd még Györi Szabó 2006, 109), amely égisze alatt az „autonómia kifejezés tabu az egyezményekben” (Györi Szabó 2006, 109).

Hannum szerint a már meglévő nemzetközi jogokból (önrendelkezési és emberi jogok, a szuverenitáshoz való jog) kellene az autonómiához való jogot egy új nemzetközi jogi elvként megalkotni. Szerinte az autonómia a különböző jogok fejlödésének a végpontján nyugszik (Hannum 1992). Lapidoth szerint az autonómia lehetöséget ad egy kisebbség számára az önérvényesítésre, sőt akár az önmeghatározásra (Lapidoth 1997) is, vagyis tekinthető akár egy kisebbségvédelmi intézménynek is, legyen az a kisebbség akár etnikai, akár vallási, kulturális vagy nyelvi értelemben vett kisebbségi csoport, közösség. De ha az autonómia nem kapcsolódik feltétlenül és szükségszerúen csupán a fentnevezett kisebbségek problematikájához, akkor is a demokratizálás és a szubszidiaritás elve mentén szükségszerü lehet (Lapidoth 2001). 


\section{Az autonómia tipológiája}

Az autonómiákat osztályozhatjuk az őket létrehozó jogi forma vagy az alanya szerint, de ezeken belül is számos típusát különítették el a szakértők. Ezek összefoglalását igyekszünk bemutatni a következökben.

1) A jogi forma és a szint figyelembevételével, amelyen szentesitették a nemzeti jog vagy a nemzetközi jog által létrehozott autonómiák két fö típusa létezik:

a) az érintett állam jogalkotója hozza létre, ilyen a Grönland és Korzika területi

és a skandináviai lappok személyi autonómiája,

b) a nemzetközi jog által létrehozott autonómia:

- kétoldalú szerződésben: Dél-Tirol és az Ấland-szigetek esetében;

- nemzetközi jogközösség döntése alapján alapvetően békefenntartás céljából létrehozott autonómia, például Irak kurd lakosságának védelme esetében.

2) Az autonómia alanyától függően megkülönböztetünk:

- személyi (perszonális) és/vagy kulturális autonómiát;

- és területi autonómiát. ${ }^{9}$

Jelen tanulmány e két utóbbi autonómiatípus részletesebb elméleti bemutatását célozza meg.

\section{I) Személyi elvü vagy kulturális autonómia}

Ez az autonómiatípus a szórványterületen, területileg nem kompakt tömbben élő kisebbségek számára nyújt személyi elvre alapulva lehetőséget saját kulturális intézmények és érdekképviseletek létrehozására, és miközben elismeri az ország polietnikus jellegét, nem bontja fel az állam közigazgatási rendszerét. Nagy előnye továbbá, hogy a vallási, nyelvi, kulturális karakterek megörzése ilyen formában saját, közjogi intézményeken keresztül lehetséges, és ezekben a kérdésekben saját döntési jogkörrel rendelkezhetnek az érintettek, az alanyok. Miközben helyi és országos hatáskörű oktatási, kulturális intézményrendszer kiépítése, fenntartása is tartozhat a funkciói közé, bizonyos hatáskörökkel soha nem rendelkezhet, mint például gazdasági vagy szociális kérdések, így tehát a területi autonómiához képest szükebb jogosítványokkal bír. A szakirodalom felhívja azonban a figyelmet arra is, hogy a személyi autonómiának nem kell csupán a kulturális és oktatási ügyekre szorítkoznia (Wolf-Weller 2005).

Ugyanakkor előnye, hogy a kisebbség minden tagja beletartozik - önkéntes alapon -, más pedig nem (nincs helyi kisebbség-többség probléma), így nehezebben szünik meg, hiszen a területi mobilitás, demográfiai változások nem érintik. Így viszont nem old meg minden kisebbségi problémát, hiszen nem tud megoldást találni például a munkahelyi vagy munkaerö-piaci diszkriminációra, a rendőrségi részrehajlásra stb. A személyi autonómia pozitívuma az is, hogy általa az érintett nemzetállam nem érzi területileg veszélyeztetve magát. 
Negatívumként a személyi nyilvántartásba vételt vagy kataszteri rendszert szokás megnevezni, amely által az érintett csoportot jegyzik. Mindemellett nyilvánvaló, hogy a területi autonómiánál sokkal kevesebb jogot biztosít, és veszélye, hogy kulturális törésvonalakat indukál (Győri Szabó 2006).

A perszonális autonómia finanszírozása teljes mértékben az államra hárul, ez nagyfokú függést jelent a központi kormányzattól. A központi kormányzásban való részvételre azonban nagyon csekély a lehetőség, hiszen a szórványnépcsoportok esetében nem tartják fontosnak a makropolitikába való beleszólási jog megadását. Lapidoth felhívja azonban a figyelmet arra, hogy a személyi autonómia esetében az állam felhatalmazza a kisebbségeket arra, hogy saját intézményeiken keresztül tegyék meg a szükséges lépéseket a saját jogaik védelmében és végrehajtását illetően (Lapidoth 1997).

A 19. század vége előtt nemigen beszélhetünk személyi vagy kulturális autonómiáról, habár az elv gyökerei messze visszanyúlnak az időben. Ez a fajta autonómia hasonlít a millet-rendszerre, amelyet az Oszmán Birodalom alkalmazott a nem muszlim, vagyis keresztény és zsidó hitủ közösségek esetében a 15. századtól, és amely a vallási és kulturális autonómia bizonyos fokát, illetve politikai stabilitást jelentett (Schöpflin 2001). A személyi autonómia elvének a nemzetiségi törvényhozásba való bevezetését a szakirodalom Kossuth Lajos nevéhez köti, aki valószínűleg a millet-rendszer hagyományaiból kiindulva a nemzeti személyi autonómiát vallási kérdésekkel együtt kezeli, ilyen formában eléggé behatárolva (Eide 1998). A személyi elv 20. századi bevezetésére jó példa az 1905-ben felépített morvaországi rendszer, amely a tartományban a cseh-német kiegyezést szolgálta. Ez a rendszer etnikailag elkülönített névjegyzékbe vételen alapult, mely listák összeállításával a helyi önkormányzatok voltak megbízva. Maga a koncepció a múlt század elején fogalmazódott meg, szellemi atyjai Karl Renner és Otto Bauer voltak, és az Osztrák-Magyar Monarchiára vonatkoztatva dolgozták ki, mint etnikai feszültséget oldó, de a területi integritást nem veszélyeztető megoldást. A mai példákat az észtországi, magyarországi, szlovéniai, horvátországi kisebbségpolitikában találjuk, az utóbbi két esetben garantált parlamenti képviselettel, míg Nyugat-Európában a skandináviai lappokat kivéve nemigen találunk ilyen jellegü megoldásokat.

Heintze ezt az autonómia típust alcsoportokra osztja, különválasztva a kulturálist, a személyi autonómiától, és bevezetve egy új fogalmat, a funkcionális autonómiát (Heintze 1998).

1) Kulturális autonómiának nevezi a kisebbség vagy csoport autonóm önkormányzatát kulturális ügyek terén. Ez tulajdonképpen a személyi autonómia kulturális témakörökre leszükített változata, célja pedig a csoport szabad kulturális fejlödése. Nem szükségeltetik minden kulturális ügyet a kisebbség vagy csoport kompetenciái közé sorolni, mindez megegyezés kérdése az érintettek képviselői és a központ között. A többségi kultúrától való elszeparálódás kivédése érdekében Heintze a párhuzamos kultúrák kiépítését tartja járható útnak. A legjobb példaként az Észtországban a két világháború között kiépített kulturális autonómiát említi (lásd erröl 
még Eide 1998, 253-255), amely az államon belül élő németeknek, oroszoknak és svédeknek nyújtott lehetőségeket. Eide (1998) a kulturális autonómiát elemző tanulmányában a kortárs ilyen jellegü autonómiák között említi az észt, litván, szlovén, horvát és orosz rendszereket, megemlítve a magyar Nemzeti és Etnikai Kisebbségek Jogairól szóló 1993. július 7-iki törvényt, amely Eide szerint bár nem használja a kulturális autonómia kifejezést, mégis jelentős autonómiát biztosít a kisebbségek számára (Eide 1998).

2) A személyi autonómia a jus sanguinis elve mentén müködik, és kisebbségi csoporthoz tartozó individuumoknak nyújtható függetlenül a létszámuktól. A csoport kialakíthat egy demokratikus testületet a kisebbség tagjainak a többség felhatalmazása által. Ideális esetben a kisebbség jogi személyiséget alkot (corporate body), például egy nemzeti tanácsot vagy arányos politikai képviseletet. Ez a jogi személy képviseli majd a csoportot vagy kisebbséget az állammal való tárgyalásokban, és felhatalmazást kap arra, hogy a specifikus kisebbségi ügyeket irányítsa. A személyi autonómia problémája a kisebbséghez való tartozáshoz kötődik, hiszen nem lehet kötelezővé tenni a csoportba való tartozás felvállalását. Ezért javasolják a kisebbséghez való tartozás és a jogi személyiségben való törvényes tagság elkülönítését. A jogi személyiség azonban nem csak azokat fogja képviselni, akik rá szavaztak, hanem az egész csoportot. A személyi autonómiára a németországi dánok esete a legjobb példa.

3) A funkcionális autonómia válogatott állami szerepek és jogok átruházását jelenti a kisebbségi csoportok magánszervezetei számára. Így a kisebbség kompetenciát kap a kultúra, média, oktatás és vallás ügyeiben, de ehhez az szükséges, hogy a kisebbségek magánszervezeteket alakítsanak, amelyek az állami befolyáson kívül esnek. A funkcionális autonómia a magánszervezetek kompetenciájára, kezdeményezőkészségére és érdekeire alapozódik, így tehermentesítve a szokásos közigazgatást néhány feladat mentén. Heintze e tekintetben is a németországi dán kisebbséget említi példaként (Heintze 1998, 20-24).

Természetesen jogosan merülhet fel a kérdés, hogy ki tartozhat az adott kisebbségi csoportba, hogyan lehet a legobjektívebben felmérni a csoporthoz tartozás jogosságát. Az erre kidolgozott gyakorlatok többfélék:

- egy merevebb megoldás az a gyakorlat, amikor az állami hatóságok sorolják az állampolgárokat etnikai kategóriákba, de ennek rugalmasabb változatában a kettős identitás felvállalása is lehetséges kettős regisztrációval;

- maguk az érintett csoportok, közösségek döntik el, hogy ki a tag;

- az individuum önkéntes vállalásán múlik, mely közösséghez tartozónak tartja magát. Ennek hátránya, hogy nem mindenki regisztrálja magát a csoport tagjának, így az aktívabb, magukat regisztrálók tevékenykedhetnek az egész közösség nevében (Győri Szabó 2006). 


\section{II) A területi autonómia}

Ez a fajta autonómia a nagy létszámú, tömbszerüen elhelyezkedő kisebbségeknél alkalmazható leginkább, mint a többség-kisebbség közötti ,,igazságos viszony” egyik alapfeltétele. Területi autonómia esetén az adott kisebbség számára megteremtődik az önszerveződés, önigazgatás, önkormányzat, vagyis az adott területen a teljes társadalom létrehozásának a lehetősége, amelyet a személyi autonómia nem képes biztosítani.

Minden területi autonómia egyedi, felelve a sajátos kulturális, történelmi és politikai körülményekre, és ennek az egyediségnek a kihangsúlyozása fontos, miközben természetesen vannak közös vonásaik is ezen rendszereknek (Lapidoth 2001).

A területi autonómiák esetében a Brunner-Küpper szerzőpáros figyelmeztet arra, hogy „ésszerü lenne az autonóm területeket ugyanazzal a hatalommal és hatáskörrel felruházni, mint az állam más régióinak megfelelő egységeit.” Ezért az autonóm térségekben nem csupán a kisebbségekkel kapcsolatos problémakörök mentén szükséges a hatalommal felruházás ,,mert ez azt jelentené, hogy a területi közigazgatás egyéb funkcióit különleges állami hatóságoknak kell átvenniük, amelyeknek az állam más övezeteiben semmilyen szerepük nincsen. Ez nagyobb helyett kisebb autonómiát eredményezne, valamint nem kisebbségi kérdésekben az államhoz való szorosabb kötődést.” (Brunner-Küpper 2004, 479-480)

A területi autonómia müködésének pénzügyi hátterét általában a központi költségvetés állja, de az autonómia kaphat adókivetési jogot is, mely nélkül elég nehézkes az önálló gazdálkodás. A területi autonómia és a központi hatalom közötti hatalommegosztás mentén az autonómiára átruházhatóak olyan hatáskörök, mint a törvényalkotási, kormányzási, közigazgatási, igazgatásszolgáltatási vagy rendfenntartási funkciók. A hatalommegosztás bizonyos esetekben akár külpolitikai jogosítványokkal is járhat (Győri Szabó 2006).

Kisebbségvédelmi funkciója többnyire akkor lehet egy területi autonómiának, ha e területen az adott kisebbség többséget alkot. Ha a térségben több etnikum él, de egyik kisebbséghez tartozó közösség létszáma sem alkot többséget, akkor egy polietnikus, multikulturális térségről beszélhetünk, és a régió egy sajátos autonómiával ruházható fel. Ez esetben az autonómia rugalmas elvei jól igazodhatnak a térség sajátságaihoz. Speciális esetekben létrehozható az ún. megosztott (shared) autonómia, olyan térségekben, ahol a nagy létszámú kisebbségi csoport a többségi lakossággal oly módon él együtt, hogy elhatárolásuk földrajzilag lehetetlen, de a személyi elvű autonómia nem elégséges az adott kisebbség problémáinak megoldására.

Lapidoth például hangsúlyozza ugyan az autonómia etnikai feszültségeket enyhítő funkcióját (a kisebbségi, az öslakosok, valamint a népek önrendelkezési joga mentén), de egyéb, például gazdasági okokat is felsorol a területi autonómiák kialakítására, és erre Hong-Kong példáját szolgáltatja. Szintén ezen szakértő hangsúlyozza a területi autonómiákban fontos szerepet játszó időtényezőt, amelyet kétféle dimenzióban is taglal: egyrészt a területiség tekintetében, amikor az egész területen egy időben 
vagy pedig szakaszonként vezetik be az autonómiát; másrészt pedig megkülönbözteti az állandó és az átmeneti, ideiglenes autonómiát, ez utóbbi esetében hangsúlyozva, hogy elöre meghatározott ideig vagy különböző tényezőktől függően tartják fenn (Lapidoth 1997). Ugyancsak az autonómiák átmeneti jellegére hívja fel a figyelmet egy másik szakértő, aki listáz egy sor olyan autonómiát, amelyek időszakosan léteztek. Ilyen volt a Népszövetség szárnyai alatt létrejött Gdansk autonóm terület (1919-39 között) vagy a Memel autonómia Litvániában 1924-39 között (Nordquist 1998).

A területi autonómia veszélyeire figyelmeztet azonban néhány hátránya is, mint például:

- a területi egyenlőtlenségekkel sújtott országok esetében a gazdaságilag fejlett autonóm régiók megakadályozhatják az állami redisztribúciót;

- a demográfiai csökkenés okán a kisebbség el is veszítheti az autonómiához való jogát (szemben a személyi elvü autonómiával);

- belső kisebbségeket hoz létre, melyek problémákat és feszültségeket generálhatnak; a régebben kisebbségnek számító közösség többségként kap hatalmat, amely az „új kisebbség” számára jelenthet esetlegesen elnyomást (Heintze 1998, 19), vagyis el kell kerülni az esetleges etnokratikus működés lehetőségét (Hannikainen 1998, 90);

- a szecesszió alternatívája sok esetben adott lehet, amennyiben az autonómiák nincsenek megelégedve az állammal, habár - mint azt már említettük- egyes szerzők a szecessziót elkerülő funkcióját hangsúlyozzák.

Az autonómia gyakorlatba ültetése számos kérdést felvet, hiszen minden autonómia egyedi a maga nemében. Mégis vannak olyan minimum-követelmények, illetve olyan alapvető kérdéskörök, amelyeknek minden autonómiára érvényesnek kell lenniük. Összefoglalóan a következő releváns kitételeket emeljük ki:

- A nyelv kérdése, mivel a maga valóságos és szimbolikus szerepével valószínűleg egy kultúra leginkább megkülönböztető jegye. Egy nyelv használatának a megtiltása egyértelmüen megengedhetetlen a nemzetközi emberi jogi normák alapján. Az autonómiáknak külön ki kell térniük a kisebbségi nyelvek kérdésére, annak hivatalos státuszt kell adniuk. Grönlandon és a Feröerszigeteken a kisebbségi nyelv egyenrangú az ország hivatalos nyelvével, de például a Áland-szigeteken a svéd kisebbségi nyelv egyedül a hivatalos, mellette az ország nyelve, a finn, marginális.

- Az oktatás a nyelv mellett az az eszköz, amely által a kultúra közvetítődik, és az autonóm régióknak vagy közösségeknek meg kell hagyni a jogot, hogy megalapozzák saját oktatási prioritásaikat.

- A kormányzati közszolgáltatáshoz való hozzáférés (beleértve a rendőrségi és biztonsági erőket) kérdése főleg a fejlődő országokban akut, mivel ez az alaptéma meghatározza a kisebbségi csoportok tagjainak a gazdasági, társadalmi és politikai befolyását. Megtörténhet, hogy egy kisebbség igazgatási szinten ki van rekesztve a kormányzati döntéshozatali mechanizmusból, de ezt az autonómiának ki kell küszöbölnie. 
- A földterület a területi autonómia elengedhetetlen része, és egy terület irányítása a helyi vagy regionális kormányzat által (a tulajdonképpeni decentralizáció) fontos egyéb pl. gazdasági életképességi és fejlődési szempontok miatt is. A földterület szimbolikus jelentése is felértékelődik egy kisebbség vagy csoport számára, hiszen kapcsolódik az identitásához is a spirituális kötelékek mentén, melyek az adott területhez kötik a közösséget, illetve összefüggésben van a fizikai biztonság kérdésével is.

- A természeti eröforrások feletti felügyelet egy komplexebb kérdéskör, mivel inkább köthető a gazdasági kontextushoz, mint a kultúrák megőrzéséhez. A természeti kincsek kiaknázásának kérdése többnyire kiélezi a helyi/regionális közösségek és a központi hatóságok közötti konfliktust még akkor is, ha az állami identitás erős. A megosztott lojalitással bíró térségekben ezek hatványozottan előtérbe kerülhetnek. A helyi erőforrás-inputok felhasználásának kérdése a gazdaságfejlesztési projektekben hangsúlyosan veti fel a helyi képviselök részvételének jelentőségét a döntéshozatali mechanizmusban. Például a Feröerszigeteken és Grönlandon a halászat az autonómiák hatáskörébe tartozik.

- A képviseleti helyi kormányzati szerkezet alapkérdés minden autonómiaigény esetében. Egy teljesen autonóm területnek alapvetően a következő hatalommal és testületekkel kell rendelkeznie:

- egy helyileg választott törvényhozó testülettel, amely a helyi kormányzati hatalom alapvető forrása, irányítja és befolyásolja az elemi és középszintủ oktatást, a nyelvhasználatot, a helyi önkormányzat szerkezetét, a földhasználatot, a regionális gazdaságfejlesztést, régión belüli szállítást;

- egy helyileg kiválasztott és a központi kormányzat által jóváhagyott legfőbb végrehajtóval (kormányzó, elnök vagy miniszterelnök), aki felelős az állami és a helyi törvények alkalmazásáért egyaránt;

- egy független helyi bírói testülettel, amely értelmezi a helyi törvényeket. A testület függetlensége nem jelenti azonban a központi bírói hatalomtól való teljes elszigetelődést.

- mindezek mellett a közös érdekek kérdéskörét az autonóm térség és a központi kormányzat közötti hatalommegosztási megállapodás szabályozza. Sok esetben a közös hatóság felügyelete alatt állnak a kikötők és a kommunikációs szolgáltatások, a rendőrség és a természeti kincsek kiaknázása. A vitás kérdések tárgyalásához szükségesnek vélik, hogy a régió rendelkezzen egy külön testülettel, mely a vitában a központi hatalom tárgyalópartnere. (Ilyen például az Åland Delegáció.)

- a helyi adók ügye és az afölött gyakorolt hatáskör szintén fontos, hiszen olyan bevételhez juttathatja az autonóm régiót, amely a gazdasági önrendelkezés alapja is lehet. 
- a más régiókkal vagy entitásokkal való kooperálás joga különösen gazdasági és kulturális téren (Hannum-Lillich 1981, 219-232; Hannum 1992, 458-468; Hannikainen 1998, 90-94).

A gazdasági kérdések kiemelt és komplex témájában Lapidoth különböző forgatókönyveket állít fel, amelyek mentén az autonóm térség cselekedhet gazdasági téren:

1) a központi hatalom megtart minden jogosítványt gazdasági téren, de az autonóm térséget érintő kérdésekben konzultál vele;

2) a gazdasági kérdések szintén a központ hatalmában vannak, de az kezdeményezési és ajánlási lehetőséget ad az autonóm térségnek a térséget illető gazdasági ügyekben;

3) korlátozott hatalma van az autonóm térségnek például az övezeten belüli kereskedelem terén;

4) az autonóm entitásnak cselekvési hatalma lehet az általános gazdaságpolitika keretei között olyan szférákban, amelyet a központi kormányzat kijelöl (Lapidoth 1997, 184-193).

A területi autonómiák rendszere jól müködik Nyugat-Európában, így sok példát említhetünk e makrorégióból. Csoportosítva őket, a következőket említjük:

- Szigetek vagy teljes földrajzi különállással bíró területek esete:

Åland-szigetek; Feröer-szigetek, Grönland és Korzika; közigazgatási okok miatt: Man-sziget, Csatorna-szigetek;

- Anyanemzettel nem rendelkezö népcsoportok, önálló nemzetek esete: Baszkföld, Katalónia, Galícia, Skócia, Wales;

- Nemzeti kisebbségek esetében:

Dél-Tirol, Valle d'Aosta, belgiumi németek.

Ezen felül számos közép- és kelet-európai példával is találkozhatunk, még ha e térségben nincs is egyelöre olyan hagyománya a területi autonómiának, mint Nyugat-Európában:

- Anyanemzettel nem rendelkezö népcsoportok esetében: Gagauzia (Moldávia).

- Nemzeti kisebbségek esetében: Vajdaság, Koszovó 1974-1989, Magyar Autonóm Tartomány (illetve később Maros-Magyar Autonóm Tartomány) 1952-1968, Krím félsziget Ukrajnában.

A speciális esetekre is figyelemmel van az Európában működő területi autonómiák azon kategorizálása (Bognár 2007), amely mind a kisebbségi vonatkozást, mind pedig az azt nélkülöző autonómiákat tipizálja, és két külön kategóriaként kezeli területi és az ún. regionális autonómiákat.

Suksi (1998) a területi autonómiák esetében azt vizsgálja, hogy az illető autonómiát megillető hatáskörök mennyire vannak „beágyazva” az alkotmányba vagy egyéb jogi keret-dokumentumba. Ez a „,beágyazottság” (entrenchment) azt jelenti, hogy az adott autonóm berendezkedésre vonatkozó jogi szabályozást nehezen lehet megváltoztatni. Suksi eszerint kategorizálja az általa vizsgált autonóm területeket: 
- általános beágyazottság: esetében az autonómia szabályozását az alkotmány explicite tartalmazza, ilyenek az Åland-szigetek, valamint a spanyol és az olasz régiók;

- fél-általános beágyazottság: esetében az alkotmány nem tartalmaz szabályozást, de az élö jog egyéb szabályozásai vonatkoznak rá, például a horvátországi régiók esetében;

- regionális beágyazottság: esetében számítanak az önálló regionális válaszra akkor, amikor az autonóm berendezkedéssel kapcsolatos törvényhozás módosul, például az Åland-szigetek, a spanyol régiók, az olasz régiók és a Krímfélsziget esetében;

- speciális beágyazottság: létrehoz egy speciális módosítási szabályt az autonómia rendelkezései számára, amely mentén a nemzeti alkotmány kereteit változtathatják, például az Åland-szigetek, a spanyol régiók, Gagauzia térségében;

- nemzetközi beágyazottság: nemzetközi megállapodás garantálja egy térség speciális státuszát, például az Åland-szigetek esetében (Suksi 1998).

Nordquist a földrajzi és történelmi meghatározottságot alapul véve osztályozza a területi autonómiákat, a következő kategorizálás mentén:

- Célszerü-célorientált-racionális-javasolt (expedient) autonómiák: amelyek gyakorlati okokra vezethetők vissza, például a földrajzi távolságra vagy más fizikai akadályra. Ilyen autonóm térség a Falkland-sziget az Egyesült Királyság esetében;

- Történelmi autonómiák: amelyek történelmi okok miatt időnként autonóm helyzetben voltak a (sokszor változó) politikai környezettel szemben, és jelenleg, beilleszkedve a modern államrendszerbe, megmaradtak autonómnak. Ilyen a Man-sziget esete.

- Szerves autonómiák: amelyek egy hosszú, békés folyamat nyomán fejlődtek ki a központi állam modern alkotmányos keretei között. A fejlödés a régió specifikus identitására alapoz, erre példa Grönland Dánia viszonylatában.

- Megragadott (seized) autonómiák: amelyek sok esetben fegyveres konfliktusok megoldásaként jönnek létre. Ilyenre példa az Åland-szigetek, Finnország autonóm térsége (Nordquist 1998).

\section{Összegzés}

A tanulmány vélhetően jól mutatja a sokszínüséget és a gyakorlatba ültetés komplexitását, amely az autonómiák velejárója. Sem elméleti, sem gyakorlati szinten nincs egységes álláspont e témakörben, a szakértők és kutatók is a saját elméleti rendszerükben igyekeznek elhelyezni azt, de magának az autonómiának még nincs kiforrott elméleti és jogi háttere. Ez természetesen következhet a gyakorlatba ültetés sokféleségéből, illetve a nemzetközi jogi szabályozás hiányából is, de ugyanakkor nagyobb mozgásteret ad az új autonómia-törekvéseknek is. 
Fontos továbbá megjegyezni, hogy a fejezetben vázolt főbb autonómia-modellek a gyakorlatban általában nem válnak teljesen szét, leginkább vegyes formában és változatokban valósulnak meg. A személyi és területi elven létrehozott autonómiák nem zárják ki egymást, sőt, sok esetben ezek kombinációjával találkozhatunk. A szakirodalom azt a nézetet támasztja alá (Varga 1995; Lapidoth 1997; Győri Szabó 2006), hogy a közép-kelet-európai sajátos etnikai és társadalmi viszonyok is ilyen kombinált autonómia szükségességét vetik fel.

\section{Jegyzetek}

${ }^{1}$ Az EBEÉ Emberi Dimenzióval foglalkozó koppenhágai találkozójának dokumentuma (1990. június 29.) (Majtényi-Vizi 2003, 195-198).

2 Nyilatkozat a nemzeti vagy etnikai, vallási és nyelvi kisebbségekhez tartozó személyek jogairól (Majtényi-Vizi 2003, 98-101).

3. Helyi Önkormányzatok Európai Chartája, Európa Tanács, Strasboug, 1985. október 15.

${ }^{4}$ Resolution 232 (1992) on autonomy, minorities, nationalism and European union, of 18 March 1992, $2^{\text {nd }}$ sitting.

${ }^{5}$ Regionális vagy Kisebbségi Nyelvek Európai Chartája, Strasbourg, 1992, ETS No. 148. (Majtényi-Vizi 2003, 136-150).

${ }^{6}$ Európa Tanács Parlamenti Közgyűlésének 1201-es ajánlása az emberi jogok európai egyezményének a kisebbségi jogokra vonatkozó kiegészítő jegyzőkönyvével kapcsolatban. (Majtényi-Vizi 2003, 151-156).

${ }^{7}$ Federalism, Regionalism, Local Autonomy and Minorities, Res. 52/1997.

${ }^{8}$ Az autonóm régiók pozitív tapasztalatai, mint a konfliktusok megoldásának lehetséges eszközei Európában (Majtényi-Vizi 2003, 184-186).

9 Ehhez a tipizáláshoz még hozzárendelhető két autonómiatípus: a helyi közigazgatási autonómia egy nemzetiség által többségben lakott településen, illetve az ún. tájegységi autonómia, mely tulajdonképpen a nyugat-európai fogalomhasználatban a regionalizmus szinonimája (Györi Szabó 2006).

\section{Irodalom}

Bernhardt, R. (1981) Federalism and Autonomy. - Dinstein, Y. (ed.) Models of Autonomy. Tel Aviv University (Faculty of Law) - Transaction Books, New Brunswick - London. 23-28. o.

Bognár Z. (2007) Kisebbségi autonómiák és a kisebbségek érdekeit szolgáló regionális autonómiák az Európai Unió tagállamaiban. RMDSZ Ügyvezető elnöksége, Kolozsvár.

Brunner, G.-Küpper, H. (2004) Európai autonómia-megoldások: a kisebbségi önkormányzatok autonómia-modelljeinek tipológiája. - Magyar Kisebbség. 1-2. 466-496. o.

Bullain, I. (1998) Autonomy and the European Union. - Suksi, M. (ed.) Autonomy: Applications and Implications. Kluwer Law International, The Hague. 343-356. o.

Dinstein, Y. (1981) Autonomy. - Dinstein, Y. (ed.) Models of Autonomy. Tel Aviv University (Faculty of Law) - Transaction Books, New Brunswick - London. 291-303. o.

Eide, A. (et al.) (1998) Cultural Autonomy: Concept, Content, History and Role in the World Order. Suksi, M. (ed.) Autonomy: Applications and Implications. Kluwer Law International, The Hague. 251-276. o.

Federalism, Regionalism, Local Autonomy and Minorities, Council of Europe, Resolution 52/1997. https://wcd.coe.int/ViewDoc.jsp?id=848841\&Site=COE (letöltve: 2009.09 .10 .)

Gerencsér B.-Juhász A. (2001) A kisebbségi autonómia (müködö modellek, magyar elképzelések). http://www.hhrf.org/autonomia/ (letöltve: 2008. 12. 05.).

Ghai, Y. (2000) Etnicity and Autonomy: a Framework for Analysis. - Ghai, Y. (ed.) Autonomy and Etnicity: Negotiating Competing Claims in Multi-ethnic States. Cambridge Univ. Press, Cambridge. 1-26. o.

Györi Szabó R. (2006) Kisebbség, autonómia, regionalizmus. Osiris, Budapest. 
Hannikainen, L. (1998) Self-determination and Autonomy in International Law. - Suksi, M. (ed.) Autonomy: Applications and Implications. Kluwer Law International, The Hague. 79-95. o.

Hannum, H. (1992) Autonomy, Sovereignity, and Self-Determination: the Accomodation of Conflicting Rights. University of Pennsylvania Press, Philadelphia.

Hannum, H.-Lillich, R.B. (1981) The Concept of Autonomy in International Law. - Dinstein, Y. (ed.) Models of Autonomy. Tel Aviv University (Faculty of Law) - Transaction Books, New Brunswick London. 215-254. o.

Heintze, H.-J. (1998) On the Legal Understanding of Autonomy. - Suksi, M. (ed.) Autonomy: Applications and Implications. Kluwer Law International, The Hague. 7-32. o.

Helyi Önkormányzatok Európai Chartája, Európa Tanács, Strasboug. $1985 . \quad$ október 15. http://www.bm.hu/web/euik.nsf/B85F6DC9E98503C3C1256DC60049C2BD/\$FILE/HELYI\%20\%C3\%96 NKORM\%C3\%81NYZATOK\%20EUR\%C3\%93PAI\%20CHART\%C3\%81JA.doc (letöltve: 2009. 08. 31.)

Lapidoth, R. (1997) Autonomy: flexible solutions to ethnic conflict. United States Institute of Peace, Washington.

Lapidoth, R. (2001) Elements of Stable Regional Autonomy Arrangements. CAP Working Papers, München.

Lewis-Antony, S. (1998) Autonomy and the Council of Europe - With Special Reference to the Application of Article 3 of the First Protocol of the European Convention on Human Rights. - Suksi, M. (ed.) Autonomy: Applications and Implications. Kluwer Law International, The Hague. 317-342. o.

Lindley, R. (1986) Autonomy. (Issues in Political Theory sorozat) Macmillan, London.

Lundi Ajánlások a nemzeti kisebbségek hatékony részvételéröl a közéletben és Értelmezö Jegyzék. (1999) Foundation on Inter-Ethnic Relations, Hága. http://www.osce.org/documents/hcnm/ 1999/09/2698_hu.pdf (letöltve: 2009. 11. 05.)

Majtényi B.-Vizi B. (szerk.) (2003) A kisebbségi jogok nemzetközi okmányai. Dokumentumgyüjtemény. Gondolat - MTA Jogtudományi Intézet - MTA Kisebbségkutató Intézet, Budapest.

Schöpflin Gy. (2001) Délkelet-Európa fogalmának meghatározása. - Provincia. 8-9. 10-11. o.

Nordquist, K.-Å. (1998) Autonomy as a Conflict-Solving Mechanism - An Overview. - Suksi, M. (ed.) Autonomy: Applications and Implications. Kluwer Law International, The Hague. 59-77. o.

Sohn, L.B. (1981) Models of Autonomy within the United Nations Framework. - Dinstein, Y. (ed.) Models of Autonomy. Tel Aviv University (Faculty of Law) - Transaction Books, New Brunswick London. 5-22. o.

Suksi, M. (1998) On the Entrenchment of Autonomy. - Suksi, M. (ed.) Autonomy: Applications and Implications. Kluwer Law International, The Hague. 151-171. o.

Thornberry, P. (1998) Images of Autonomy and Individual and Collective Rights in International Instruments on the Rights of Minorities. - Suksi, M. (ed.) Autonomy: Applications and Implications. Kluwer Law International, The Hague. 97-124. o.

Varga A. (1995) Autonómiaformák. Lehetőségek és következmények. - A Hét. 28. http://adatbank.transindex.ro/html/cim_pdf536.pdf (letöltve: 2010. 01. 05.).

Vizi B. (2004) Autonómia és európai integráció. - Magyar Kisebbség. 1-2. 226-235. o.

Wolff, S.-Weller, M. (2005) Self-determination and autonomy.-Weller, M. - Wolff, S. (eds.) Autonomy. Self-governance and Conflict Resolution: Innovative approaches to institutional design in divided societies. Routledge, London - New York. 1-25. o.

\section{AUTONOMY: THEORY AND PRACTICE}

\section{ANDREA MIKLÓSNÉ ZAKAR}

Autonomy has remarkable tradition in the West European macro region, but also tends to become one of the most determinative issues in East Central European countries. Based on English and Hungarian scientific literature this study tries to reveal the theoretical aspects of autonomy together with the complexity of its practical application. The author wishes to collect and summarize the different autonomy definitions published by scientists like Ruth Lapidoth, Hurst Hannum, Hans-Joachim Heintze and so on. The study also analyses those international documents which refer to the principle of or the right to autonomy. The second part of the study presents the two main types of autonomy: the cultural/personal and the territorial one. 


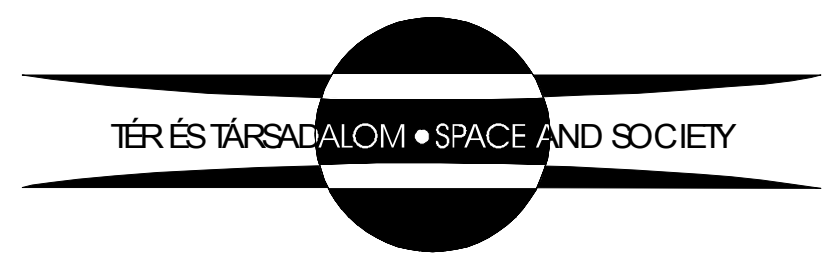

